\title{
Transition of Youth from Education to the Labour Market: the Case of Lithuania
}

\author{
Ruta Braziene and Agne Dorelaitiene
}

Kaunas University of Technology

Donelaicio 73, LT-44029 Kaunas, Lithuania

cross $^{\text {ref }}$ http://dx.doi.org/10.5755/j01.ss.77.3.2768

\begin{abstract}
This paper discusses the transition of youth from education to the labour market in Lithuania. The purpose of this research is to identify trends and disclose main opportunities and essential challenges for a successful transition of youth from education to the labour market in Lithuania. The research problem can be defined by the following questions: what are the trends of youth transition from education to the labour market in Lithuania? What is the perspective for youth employment in Lithuania?

Semi-structured interviews with experts working in the areas of employment, education, economy at the national level were carried out. The research results revealed that the main challenges concerning successful youth transition from education to the labour market are the following: the supply of professions mismatches the demands of the labour market, there is lack of compliance between educational system and labour market demands, youth often lacks necessary skills and personal qualities for a particular working place, Lithuanian lacks more profound labour market forecasts, etc.
\end{abstract}

Keywords: youth, education, transition, labour market.

\section{Introduction}

Youth employment remains a significant problem in most European countries. Young people generally face much higher risks of being unemployed than adults: youth does not have practical experience and knowledge related to work. Research in most Western European countries is targeted towards the analysis of youth transition to adulthood, youth school-to-work transition patterns, education-job mismatch, social, labour market policies and etc. However, in Central and Eastern Europe, analysis of those issues is rather limited. There are almost no studies or empirical research directly targeted towards analysis of young person's transitions from education to the labour market.

Almost all Central and Eastern European countries inherited highly centralised educational system. School structure and content of education was divided in two directions: general and professional. Young people were allocated to the education system in accordance with the economic and social goals of central planning. Relation between the level of education and future perspectives in the labour market was clearly determined. Transition from education to the labour market was fluent. Due to the study achievements first working place for the young people was guaranteed by the state (Saar, Unt and Kogan, 2008).

During the last 15 or 20 years due to social, economic, political and technological changes, migration, modification of the family structure reshaped the average life cycle. Stable job, separate house, family and children lost its position as the threshold of the social maturity value. Young people can leave their parents' home without creation a new family, obtainment of stable job and etc. Cooperation between employees and schools is rather scarce and both these systems participation into youth integration into labour market is rather limited (Saar, Unt and Kogan, 2008).

The issue of transition from education to the labour market and employment has been a focus of policy and research concern across the many Western European countries for at least 30 years. The following directions of research can be distinguished:

- Youth education/labour market transitions processes (Gracey and Kelly, 2010; Keep James, 2010; Raffe, 2008; Müller and Gangl, 2003; Hodkinson et al., 1996; Shavit and Muller 1998);

- Employer dissatisfaction with the education system's products (lack of employability and work readiness among the young) (Livingstone, 2010; Gleeson and Keep, 2004);

- Job quantity and quality (part time, temporary jobs, unsatisfied, unpleasant and boring jobs) (Green, 2009; Howarth and Kenway, 2004);

- Integration into labour market of youth (Pocius, 2012; Okuneviciute-Neverauskiene and Moskvina 2008; Okuneviciute-Neverauskiene and Slekiene, 2008; Beresneviciute and Poviliunas, 2007; Mihaela, Coralia and Cosmin, 2010; Coenjaerts et al., 2009; Biffl, 2008; Bucher, 2008; Karamessini, 2010; Van der Velden and Wolbers, 2003; Van der Velden, Welters and Wolbers, 2001; Cuesta, 2005);

- General youth employment levels (UKCES, 2011).

The unemployment rates of young people have increased considerably during the last decade in Lithuania. According to Eurostat data, in the second quarter of 2012, the unemployment rate of youth (aged 15-25 years) was 25,6 percent - it was 12,3 percent of all registered 
unemployed. Employment prospects of young people considerably affected by their gender, educational attainment, previous work experience and etc. Risk or vulnerability of young people in the labour market is not mostly related of attaining first job of short and unstable duration. The possibilities of attaining decent, safe, stable, long term job becomes more and more complicated and challenging for youth.

Moreover, social and economic changes reveal the complexity of the youth transition from education to labour market in Lithuania. Lithuanian youth faces specific challenges in finding decent employment: young persons are in the risk of losing their jobs during economic downturns (according to the principle: 'last in, first out'); lack of experience prevents entry to the labour market; low wages force youth emigration abroad; dealing with paid studies young persons combine unqualified jobs and studies or postpone study completion for later. In youth life path there are no stability as it was in previous generation: educational attainment do not guarantee decent work, in some cases young people with high level education work unqualified job with low wages.

The research problem analysed in this paper can be defined by the following questions: What are the trends of youth transition from education to the labour market in Lithuania? What is the perspective for youth employment in Lithuania?

The aim of this paper is to disclose the main opportunities and essential challenges for youth transiting from education to the labour market in Lithuania.

The following research methods were employed: comparative and systematic analysis of research literature and interviews.

First part of the article provides a theoretical framework, discusses concepts of transition from education to the labour market; the second part - applied survey research methodology. Third part is devoted to analysis of interviews carried out with the experts representing educational, labour market and other institutions.

\section{Transition from education to the labour market: theoretical background}

The concept of transition from education to the labour market

The school-to-work transition is defined as the passage of a young person (aged 15 to 29 years) from the end of schooling to the first regular or satisfactory job.

Transition from education to the labour market characterised as dynamic process in which person transits from educational system to satisfactory and stable job. The main institutes of transition are educational system and labour market. Transition stage from one system to another discloses that this process is not only consequence of individual resources and characteristics. This process is regulated by the external factors, while individual resources are determined by the institutional contexts, especially, agreements between educational, employment systems and relationships between those two institutions (Saar, Unt and Kogan, 2008).
The concept of 'transition system' refers to the relatively enduring features of a country's institutional and structural arrangements which shape young people's transitions (Ianneli and Raffe, 2007). Researchers have explained transition patterns in terms of characteristics of labour market (Garonna and Ryan, 1991) and educational systems (Allmendinger, 1989). The linkages with the labour market (Hannan, 1996) the scale or tertiary education and the occupational specificity of vocational education (Muller and Shavit, 1998).

Researchers define three stages of transition from education to the labour market (Matsumoto and Elder, 2010):

Transited - A young person who has 'transited' is one who is currently employed in:

- A regular and satisfactory job;

- A regular but non-satisfactory job;

- A satisfactory but temporary job;

- In satisfactory self-employment.

In transition - A young person is still 'in transition' if s/he has one of the following statuses:

- currently unemployed;

- currently employed (wage \& salaried worker) with no contract;

- currently employed in a temporary and nonsatisfactory job;

- currently self-employed and unsatisfied; or

- currently inactive and not in school, with an aim to look for work later.

Transition not yet started - A young person who has 'not yet transited' is, one who is either of the following:

- still in school;

- currently inactive and not in school, with no intention of looking for work.

Regular employment is defined in terms of duration of contract or expected length of tenure. The contrary is temporary employment, or employment of limited duration. Satisfactory employment is a subjective concept, based on the self assessment of the job-holder. It implies a job that the respondent considers to 'fit' to his desired employment path at that moment in time. The contrary is termed non-satisfactory employment, implying a sense of dissatisfaction about the job.

The school-to-work transition refers to four aspects:

- Individual aspect - the period in one's life between completion of general education and the beginning of gainful employment - individual aspect;

- The institutional aspect -training systems, institutions and programs that prepare young people for employment after completion of general education;

- $\quad$ The training market aspect - the transition from school to vocational training (first threshold);

- The labour market aspect - the transition from vocational training to work (second threshold) (Rauner, 1999, p. 1).

Education and social capital

Education is a crucial determinant of people's prospects in life, and educational consequences on life chances are mainly mediated through the labour market and the work positions people with different kinds and 
levels of education are able to obtain (Muller, Gangl, 2003). Each actor attempts to reach an optimal solution, given his or her preferences and the available opportunities. Education increases probability of finding employment. Education plays a crucial part in the matching process. Employers try to recruit those applicants they consider to be both most productive and least costly for the kind of work the job requires. Qualifications are an important signal for employers to assess the productivity and costs of workers. Better-educated people are more likely to be in work, and if economically active, less likely to be unemployed (OECD, 2001, p. 28).

During industrial society period, the main factors of production were land, labour and physical capital. Begging in the early 1960s, quality of labour became important factors, especially the level of education and training in the workforce. As Organization for economic co-operation and development (OECD, 2001) notice, it gave rise to the concept of human capital, which is a well-established part of standart economic theory nowadays (Robeyns, 2006). Organization for economic co-operation and development (OECD, 2001, p. 18) human capital defines as the knowledge, skills, competencies and attributes embodied in individuals that facilitate the creation of personal, social and economic well-being. Human capital is emobodied in individuals and grows thoruogh use and experience inside and outside employment, as well as through formal and informal learning. Moreover, human capital is a heterogenous concept because skills and acquitance required for people are changing through interpersonal communication, self-reflection and self-directed learning. In some countries, wages which usually depend on qualifications are very large, reflecting a greater wage spread in the labour market and possibly higher returns to particular skills (OECD, 2001). As Robeyns (2006) notices, human capital theory considers education relevant in so far as education creates skills and helps to acquire knowldge that serves as an investment in the productivity of the human being in ecnomic productuon factor that is a worker. Thus education is important because it allows workers to be more productive $<\ldots>$ by regarding skills and knowledge as an investmen in one's labour productivity, economists can estimate the economic returns to education for different educational levels, types of education (Robeyns, 2006, p. 72)

Also human capital approach suggests that individuals with higher educational attainments will have higher probabilities of employment (Smith and McCoy, 1999; Lynch, 1989). There is also a well-established expectation that the longer an individual is unemployed the lower is the probability that the individual will escape from unemployment and re-enter work (Heckman and Borjas, 1988).

Employers demand workers who are not only more skilled but also flexible and 'trainable'. Individual workers respond by upgrading on a strong platform of initial education and generic employability skills to achieve better employmentopenings. More intensive demand for 'shared knowledge' and organisational capital at the level of organisations and firms implies a demand for not only more skilled individuals, but also for more effective management practices team working and flexibility (OECD, 2001, p. 27). It shows that in transition from educational system to labour market qualification isnt's the main factor in searching a work, otherwise, individual characteristics and social networks are useful too. The latter is described as social capital by such authors as Coleman (1988), Putman (1995), Bourdieu (1986).

Pierie Bourdieu was the first one who presented systematic contemporary analysis of social capital in which he defines the concepts as the 'aggregate of the actual or potential resources in which are linked to the possession of a durable network of more or less institutionalized relationships of mutual acquaintance and recognitions' (Bourdieu, 1986, p. 248; in Ortega, 2011). This concept by Bourdieu is associated with an individual perspective and as Porte notices (1998, in Ortega, 2011), highlights benefits which individual gets from being a member in a group. In Bourdieu analysis, offered 20 years ago, he asserted, 'the profits which accrue from membership in a group are the basis of the solidarity which makes them possible' (Bourdieu, 1973, p. 249, in Ortega, 2011). Coleman suggests collective perspective of social capital. According to him, social capital is a variety of different entities, with two elements in common: social structure and certain action of actors within the structure (Coleman, 1988, in Ortega, 2011).

Organization for economic cooperation and development (OECD, 2001), social capital define as networks together with shared norms, values and understandings that facilitate co-operation within or among groups. Networks are associated with objective perspective and objective behaviour of actors who participate in social activity. While shared values and norms are associated with subjective perspective of individual and group. As OECD (2007) notice, sociologist sometimes speak of norms as society's unspoken and largely unquestioned rules. OECD social capital divides into three main categories:

- 'Bonds. Links to people based on a sense of common identity ('people like us' - such as family, close friends and people who share our culture or ethnicity. Friends and families can help us in lots of ways emotionally, socially and economically. For example, in the United Kingdom, a government survey founded that more people secure jobs through personal contacts that through advertisements. Such support can be even more important in countries where the rule of law is weak or where the state offers few social services: clans can fund the education of relatives and find them work, and look after orphans and the elderly'.

- Bridges. Links that stretch beyond a shared sense of identity, for example to distant friends, colleagues and associates.

- Linkages. Links to people or groups further up or lower down the social ladder' (OECD, 2007, p. 103104).

Coleman suggests that unlike economic capital, which exists in such things as machinery, and human capital which is created by changes in persons thus making possible new acts, social capital describes relationship between people. In this respects, social networks can be 
considered to be a form of social capital that resides with families and the communities in which they live when, like other forms of capital, they facilitate productive activity. Social networks, for example, are productive when they provide trustworthy advice to individuals about the quality and the availability of particular forms of employment (Strathdee, 2001, p. 312).

Granovetter (1974) challenged this assumption by showing that access to jobs was often determined by social networks. Unlike the open labour market where all job seekers are thought to compete on the same footing, recruitment through social networks is difficult for those who have little access to these networks. According to Granovetter, there are different kinds of networks. His argument is that the use of 'strong ties', or the networks that are associated with family members or close friends to find employment, limits social mobility. This is because it only exposes individuals to opportunities that are at the same level of the labour market as their immediate social class group. In Contrast 'the weak ties', or networks that are associated with acquaintances, are more likely to promote social mobility (Strathdee, 2001, p. 314).

Symonds argues that the education and training system produces a large numbers of people that are not ready for work and employment: 'the traditional story about youth unemployment, transitions into the workplace and the skills of those leaving the education and training system in the UK has been one that has revolved around accusations that the education and training system produces large numbers of young people who are not readily 'employable' and who lack the skills, knowledge and attitudes required to perform well in the modern workplace' (Symonds et al. 2011).

Analysis of theoretical literature revealed that the trends of the transition from education to work process could be analysed at micro and macro levels. From a micro perspective is stressed labour market participation of graduates, occupational status, education-job mismatch, the role of social and human capital and etc. From a macro perspective the main role plays national context, labour market structure and institutions, educational system and etc.

\section{Research methodology}

The empirical research is targeted towards analysis of Lithuanian youth transition from education to the labour market. Specialists in the areas of employment, education, economy at the national level constantly dealing with the issues of youth transition from educational system to labour market are able to offer multidimensional and comprehensive view towards the process of transition from education to employment. In this view, semi-structured interviews with experts working in the areas of employment, education, economy at the national level were included in the initial stages of the study 'Transition of Lithuanian Youth from Education to Labour Market: Development of Monitoring System (TRANSMONITOR)' financed by the Research Council of Lithuania in order to look at the analysed problem from the perspectives of different domains. Semi-structured interviews were aimed at identifying evaluation of youth situation in labour market, evaluation of educational system, evaluation of labour market, evaluation of dialogue/coherence between educational system and labour market etc. Sampling of the experts was based on the following criteria: (1) represented domain (labour market, educational system, policy making, policy implementation); (2) a professional in a certain field related to educational system and/or labour market. Characteristics of the interviewed experts are provided in details (Table 1).

Semi-structured interviews with experts representing different domains helped to identify categories and subcategories reflecting youth situation, problem areas and future prospects in the process of transition from education to employment. Data were analysed by qualitative method of content analysis constructed of four steps: multiple reading of the text; identifying of manifest categories based on key words; dividing the categories into subcategories; interpreting of the categories and subcategories and the main categories with the help of the interview transcripts.

Table 1

Experts' characteristics

\begin{tabular}{|l|l|}
\hline \multicolumn{2}{|c|}{ Characteristics of the experts } \\
\hline Sample size & $\mathrm{N}=9$ \\
\hline Gender & $\mathrm{M}=3 ; \mathrm{W}=6$ \\
\hline Acquired education & Higher education \\
\hline \multirow{5}{*}{ Represented domain } & Policy making, policy implementation ${ }^{1}$ (Interview No.1) \\
\cline { 2 - 2 } & Chairwoman representing an organisation of people with disabilities (Interview No. 2) \\
\cline { 2 - 3 } & Labour market (Interview No. 3) \\
\cline { 2 - 2 } & Educational system (Interview No. 4) \\
\cline { 2 - 2 } & Head of organisation representing interests of rural communities (Interview No. 5) \\
\cline { 2 - 2 } & Labour market (Interview No. 6) \\
\cline { 2 - 2 } & Educational system (Interview No. 7) \\
\cline { 2 - 2 } & Labour market (Interview No. 8) \\
\hline Average duration of an interview & 1 hour 6 minutes \\
\hline
\end{tabular}

\footnotetext{
${ }^{1}$ The interview involved two experts.
} 


\section{Attitudes towards Lithuanian Youth Transition from Education to Employment: Results of Expert Interviews}

Youth - age of advantages and drawbacks

During the interviews, youth has been identified as a specific group of young people with more opportunities for acting, mobility, traveling and no living or work place attachment. Young people have been admitted to 'even benefit from their age in respect to other age groups' (Interview No. 7), as e.g. special schemes for business start-up, preferential credits, free business consulting have been devised for young people under 29. Nonetheless, the experts have noted that a young person wishing to start business in Lithuania finds it 'more difficult not only due to lack of experience with capital experience, but also due to the lack of initial capital' (Interview No. 7) and because of 'a huge burden' (Interview No. 4), which makes business 'difficult and inadequate to sustain' (Interview No. 7). Experts pointed out that Lithuania lacks a system providing support for implementation (Interview No. 5) of business ideas by ensuring preferential credits and providing all the information about what to do and how to do it in order to start business.

Other important drawbacks of the age in a broader sense have been linked to the speculation that young people are undecided about profession and future job (' $d o$ not really know what they want', Interview No. 8) and have inadequate self-esteem. Four experts have identified such situation when a young person does not know what he wants as a problem: 'If a young person graduates from secondary school and heads right away to the next step in education, it later turns out that a significant number of young people do not actually know what they want to do for a living' (Interview No. 7), 'the problem is that a young person does not know what he wants' (Interview No. 4), 'clearly not many of them know what they really want. The problem I see is that they do not want to want anything' (Interview No. 8). This is related to a young person's normative path to a certain extent, where there is a norm that after graduating from secondary school a young person proceeds to a higher step in education without any pause. 'I find the path secondary school-university very wrong', - argued the representative of educational system (Interview No. 7), whereas specialists in social policy (Interview No. 1) compare this situation to other countries, 'where it is natural for youth to not rush to further studies or employment after graduation from secondary school, they rather choose to 'find themselves' by travelling, engaging in voluntary work or other activity.' Voluntary work as a certain niche where one could develop practical skills and learn what he/she wants has also been mentioned in interviews by other experts: $<\ldots .>$ 'voluntary work should $<\ldots>$ follow secondary school. In particular for those who don't know what they want, what they want to do or study' (Interview No. 4); 'work experience and development of competencies are possible not only through employment, but also through voluntary activity' (Interview No. 7). Voluntary activity in appealing areas may help a young person decide on the desired profession and career path and evaluate employment and market in an adequate way.

Inadequate self-esteem has been identified as one of the drawbacks of young age. Experts consider young people to be inadequate in evaluating themselves, focusing on higher pay, not realizing they lack experience required by a certain profession or workplace: 'Another problem is a rather inadequate self-esteem after graduation' (Interview No. 4); 'Significant number of young people who have graduated from secondary school want to earn big money right away' (Interview No. 8); <...> 'they are interested in salary and employment conditions in the first place rather than the idea of the job $<\ldots>$ but the youth views the material basis as the most important' (Interview No. 5); '<...> they have no experience but want a wellpaying job. They never say they are going to work for 1000 Lt for a while, gain experience and then earn more. The youth have great demands $<\ldots>$ some of them have too high expectations' (Interview No. 3). However, a representative of labour market argues that for a young person to understand his actual chances for employment conditions and salary, a dialogue between an employer and the young person is necessary: 'But you can explain to him that he has no experience and you are going to instruct him for the first three months of probation' (Interview No. 6). Probation period for a young person should be the period when he/she discovers his/her potential for employment, abilities of learning and acquiring new skills necessary for professional activity.

\section{Social network vs. individual self-determination}

Inadequate self-esteem, desire for high salary may be originating from a young person's social network. Interviews with the experts have revealed that the choice of a future profession depends on how prestigious, how trendy the profession is, whether the studies are easy or not, as well as on friends and parents' influence. Most of the experts believe that a young person's choice of profession is conditioned by trends, popularity and prestige of specialities: 'we still have this old view that after graduation from secondary school it is important to proceed further with the studies, no matter which, what matters is that it is as prestigious speciality as possible, (Interview No. 1); 'I think the main argument is the trendwhere everyone else applies, $<\ldots>$ that the profession is prestigious, that you do not feel ashamed saying you have a diploma in that field $<\ldots>$ most of them really have no idea who they want to be and choose their study path by looking at what's trendy. Today they find management, law trendy' (Interview No. 7). However, the specialist in social policy has noted that statistics shows that law and management remain the fields where young people have fewer chances to find a job matching their speciality: 'Statistics showed that as at 1 June 2012 the largest number of people registered with the Lithuanian Labour Exchange were those who graduated with higher education diplomas in business management, law, social work, economics, social education, public administration' (Interview No. 1).

Preference towards popular and trendy professions may be related to the character of the studies. Experts 
suggest that social sciences may seem an easier study path if compared to information technologies, biochemistry or engineering: ' $a$ view popular among youth is that these subjects are easier to study than exact sciences; they are also viewed as 'cleaner', physically easier' (Interview No. 1); 'I think the youth chooses professions that are easy to study, to put it simply, they choose the areas that do not require learning or studying at all, what matters is student parties. <...> The problem is that they choose profession not by what they like, enjoy, but by what is easier, simpler to study, where exams are easier to pass without much studying' (Interview No. 8); 'and a student chooses easier areas when applying' (Interview No. 3). This may be related to applicability of a certificate in social sciences in various areas: 'Sure, this may be the advantage of our education where you graduate from university and can work in various areas, opt for training as you possess certain competencies of analysing, making conclusions and applying it all' (Interview No. 7). However, the idea of a trendy and easy to study profession is usually shaped in a young person's mind under the influence of close people, i.e. parents and friends. Opinion of the latter is a deciding factor in choosing further path and making decision on the desired occupation: '<... > my friends applied and I applied, this is quite common' (Interview No. 7); 'I would say that the primary influence on speciality choice comes from close relatives' speciality, parents' occupation' (Interview No. 4); 'they follow market trends, what they see on $T V$, what their friends tell them' (Interview No. 8); 'young people's opinion is very often determined by mass media, relatives, friends, the desire to have a prestigious and wellpaid profession and opportunity to earn big money in short time' (Interview No. 1).

Relatives and friends' influence is important not only in choosing a profession and deciding on the life path, but also in job seeking and starting a career. Relatives and acquaintances' contacts, employment relations are among the major mechanisms for finding a job. This statement has received approval from 5 experts: 'social network is also rather significant - opportunities it offers are usually used by the young people who are more prone to communicate, who are more active, easily noticed by employers or people close to employers' (Interview No. 1); 'as sad as it is, there is still a circle of relatives, acquaintances, close people' (Interview No. 4); 'contacts, networking are very important in finding a job' (Interview No. 8); '<..> but for the youth to find a job, acquaintances and their references are one of the major mechanisms of finding a job, (Interview No. 3). This idea has also been supported by the Chairwoman representing interests of people with disabilities who has shared that it is close to impossible to find a job for a young person with visual impairment, 'unless there is someone among close people who cherishes him, but on more beneficial conditions, if there is blood relation' (Interview No. 2). However, the expert of labour market has noted that relations and social network of acquaintances is not necessarily limited to people close to a young person. This might also be contacts established by a young person himself/herself, employment relations: 'still, contacts, relations may be established by a student during his/her activities, there are numerous business events for society, seminars, meetings, i.e. places where you might meet one or more potential employers. It is important to try to establish those contacts, show yourself, try to present yourself, try to be the first to start conversation' (Interview No. 8). The expert has further noted that more places appear, where a young person can present himself/herself or just familiarize with the professional niche: 'I was asked and agreed to participate in a series of open seminars at one school of higher education one summer. Those were open, anyone could come, not only top managers, but also students and the unemployed. Information was available for everyone, seminars were free of charge. There I didn't see young people who would come and try to come to such events. These are the events where potential employers come' (Interview No. 8). Hence, social network in a young person's life may involve not only close friends or parents, but also relations and contacts directly related to the studied area and desired work activity. However, not all young people are able to find a job even if they use the advantages of their social networks, activities or suitability of a profession - current labour market shows high rate of unemployment, economic downturn, where a young person finds himself/herself in even worse situation when seeking for the first job.

\section{Supply of professions mismatches the demands of the} labour market

'Complicated' (Interview No. 1), 'rough' (Interview No. 7), 'difficult' (Interview No. 4), 'sore' (Interview No. 2) - these are the words the experts have used to describe current situation for a young person in labour market. Youth unemployment is related not only to national and global economic difficulties, but also with the issues such as non-compliance of the acquired profession to the market demand, lack of professional training and competencies. Experts believe young people choose specialities not taking into account market demands: 'non-compliance between youth's specialities, qualifications and labour market demands' (Interview No. 1); 'young people study specialities the market does not wish to pay money for' (Interview No. 8). Still, even today 'Lithuanian Labour Exchange prepares only short-term (up to 1 year) forecast of demand for qualifications and qualified specialists, employer surveys to identify future vacancies that lack enough specialists to be prepared by educational institutions' (Interview No. 1). This suggests that Lithuania misses more profound labour market forecasts that could help a young person find the right path in choosing the profession of his/her life. It is also possible that the problem of non-compliance between a profession and labour market demands could be related to the above mentioned motive of choosing the profession - the trend. According to the representative of labour market, young people study following the trend: "there is lack of certain specialities and excess of other specialities' (Interview No. $8)$. Therefore, as the expert representing interests of the industrialists argues, young people should be more active and reasonable in choosing the place to study' (Interview No. 3). 
A young person's consciousness and activity may help a lot during traineeship, i.e. when he/she is given the chance to have a close-up view of the studied profession and acquire more skills. Still, experts argue that the lack of practical skills, experience and competencies is also an obstacle for a young person's successful integration into labour market after acquiring the qualification: $<\ldots>$ 'but $a$ student lacks practical skills, experience related to certain work' (Interview No. 1); 'education not always means that the person has the skills; a person graduates from a school of higher education, college, but does not really have the knowledge or competencies' (Interview No. 7); '<...> the main problem with it is that they don't have experience' (Interview No. 4). Experts have also identified possible areas for development of traineeship opportunities. Employers have mentioned lack of dialogue on the side of an educational institution that does not tell the employers what the trainee should learn during traineeship: 'The traineeship supervisor could advise where to focus more if he knew where the traineeship was to take place'. (Interview No. 6), but did not deny that in certain cases the place of traineeship, in particular business, was not ready to accept the trainee: 'companies themselves are not ready to accept trainees, as basically, as I remember from previous times, companies give them tasks not related to their traineeships: handle papers, do simple works. Maybe the business does not know how to treat trainees'. (Interview No. 8). This reveals a rather complicated situation with a young person in the centre: while traineeship during the studies might not be effective in providing necessary competencies and skills, practical experience is one of the prerequisites when seeking for a job.

The role of professional qualifications and personal characteristics

Profession relevant for current labour market and experience, ability to perform specific tasks remain the most important criteria in finding the first job. According to the experts, labour market is oversaturated with representatives of social sciences; there is the lack of people coming from exact, engineering sciences; therefore, young people who have acquired currently untrendy professions have the best prospects for successful integration into labour market: 'rather wide possibilities are also open for those who have chosen exact sciences medicine, physics, information technologies etc.' (Interview No. 1); 'I believe the person with high education certificate in engineering will have more chances to find a job than a person with a certificate in management, because there is countless number of managers' (Interview No. 7). Experts also emphasize that there is lack of vocational school graduates: 'graduates from vocational schools have more chances to find a job than graduates from Bachelor studies in economics, management' (Interview No. 4); 'a qualified specialist with sufficient vocational education has more chances to find a job' $<\ldots>$ 'but vocational education, specialists from vocational schools are what is currently missed the most' (Interview No. 8); 'we should not underestimate the so called labourers - the demand for these workers is quite high' (Interview No. 1). This idea has been supported by the representative of labour market who has stated that the company can employ 4-5 workers at once; the company initiates the event to search for workers by itself, visits vocational schools: 'We also hire young people who want to learn technical things; we employ a lot of such people. This spring we went to Kédainiai vocational school and to Vilkija. We made presentations about our company, but there was no feedback. Even the chief of one department of our company handed his business cards in person. Where did all those hundreds of people go?' (Interview No. 6).

In modern society a certificate of higher education is not the only mechanism opening the door into labour market. The profession and speciality are what becomes important, and they become useful only if they comply with the expectations of labour market. Besides the right qualification, acquired practical experience is also important: 'it is not the certificate proving knowledge, but the acquired experience what has become the essential factor" (Interview No. 1); "most of the employers tend to hire people with experience and I think it is difficult for the one not having any experience $<\ldots>$ traineeship is one of the major aspects a person with higher education should have' (Interview No. 4); 'it is important for an employer that a person has experience and does his job well, is not lazy, does not require someone to stand next to him and push to work' (Interview No. 5). Last expert's thought reveals yet another aspect required in seeking for a job: a young person must possess "right" personal qualities. A young person is expected to quickly adapt to new technologies, has a motivation for activities, be sociable and capable of learning at the new work place: 'sociability, curiosity, creativity, responsible attitude, attentiveness, desire to learn and develop' (Interview No. 1); 'if a young person is initiative, active and self-confident, he/she will always have more possibilities to find a job than a more passive young person' (Interview No. 7); 'I believe even if it does not match perfectly, those who are goal-focused always find their way' (Interview No. 2); 'those who are brainy, full of energy have no limitations in the labour market' (Interview No. 8). Such personal qualities are also related to a young person's motivation for acitvity during the studies: whether he was active, had certain interests, or just a passive student; activity during the studies is viewed as one of the determining factors in finding a job.

Experts admit that even if holding a certificate of a trendy profession, a young person has all chances to successfully integrate into labour market if he/she is committed to the profession: 'we could say that young people who studied well and are committed to their field of science/studies find themselves in a better position - the speciality is not actually so important, as there will always be a demand for prospective best specialists in respective fields' (Interview No. 1); 'it is important that a person likes the profession he has chosen' (Interview No. 8). This factor may also be related to a young person's activity during the studies: his/her involvement in various activities, thus developing professional knowledge and/or skills of working in a team, planning and organisational skills. Extracurricular activity during the studies is a signal to an employer that a young person seeks knowledge and 
practical skills, improves personal qualities: 'good prospects could be promised to the young people who are inclined towards activity - they participate and are active contributors in various organisations, projects' (Interview No. 1); 'but I am 100 percent sure that if there are two candidates with similar certificates, but one of them has graduated from secondary school, while another has graduated from secondary school, implemented three ideas, organised an event, knows how to attract budget, has done a multitude of other things, I am sure the employer will hire the second candidate rather than the candidate who just studied well, but did nothing else. The second candidate would be more versatile as he/she had practical skills and would not be afraid to share his/her ideas and implementing them' (Interview No. 4). The representative of labour market has stated: 'I value such things, for example, what they did during the studies if they didn't work, what extra activities they had: did the person participate in student activity, various student organisations, what he/she did, his/her interests' (Interview No. 8).

The discussed qualities and factors for successful integration into the labour market raise another question: what kind of people are most vulnerable to the risk of becoming a long-term unemployed? The interviewed experts named several risk groups such as young women and young mothers, recent secondary school male graduates and youth living in rural or remote areas. However, there are different limitations for each risk factor in job seeking or career development.

Recent secondary school male graduates and persons without qualification are viewed by the experts to have 'very narrow range of works they could do' (Interview No. 7). Lack of education or profession for a young person closes the door into the world of better or higher-paid jobs and pushes him to the labour areas where he is not required to have any specific competencies or skills and is paid minimum. Experts believe the situation of such young people is not very promising: 'positions of young people who have recently graduated from secondary school is becoming worse - they usually have nothing else to do but focus on the jobs that require low qualification' (Interview No. 1); 'this significantly narrows the opportunities for employment' (Interview No. 7); 'I think they have very little chance. Just for the fact that lots of people with high education, not only Bachelor's, but Master's as well, are registered with the Labour Exchange. <..> Of course, there are those who find jobs, but their opportunities are very narrow' (Interview No. 4). Education is named among the prerequisites in job seeking, but certain experts linked the system of higher education to trends and just general education that becomes 'the lowest threshold' (Interview No. 1): 'in Lithuania we have this trend that no matter whether you need the education or competencies or not, an employer still chooses to quote these requirements' (Interview No. 4); 'such education is treated as a kind of general education' (Interview No. 1); 'I myself find higher education helpful just on general terms' (Interview No. 6). At this point a rhetorical question could be raised of how is it possible for a young person to deal with the process of transition from education to employment in such a situation?

Gender is important issue in transition process: young women and young mother have difficulties in career. Employers view a potential mother in a young female candidate that would invoke changes in personnel at a later stage, which would leave no vacancy for a young mother coming back from maternity leave because of the pause in her career: 'there have been cases when young women face discrimination as there is higher chance they are going to have a maternity leave' (Interview No. 1); '<...> if your age is 25-28 and you are not married yet and have no children, there is a big chance you are going to very soon' (Interview No. 7); 'I know certain establishments that do consider this when hiring young women, as this is the age when they are going to have maternity leave, and the company will again have to make personnel changes' (Interview No. 4);

Table 2

Categories and subcategories identified based on the data from the semi-structured interviews with the experts

\begin{tabular}{|c|c|}
\hline Categories & Subcategories \\
\hline \multirow{5}{*}{ Youth-age of advantages and drawbacks } & Young age as a privilege \\
\hline & Difficulties in youth's entrepreneurship \\
\hline & Inadequate self-esteem \\
\hline & Indecisiveness in transition process \\
\hline & Voluntary activity \\
\hline \multirow{4}{*}{ Social network vs. individual self-determination } & Prestigious profession \\
\hline & Peculiarities of profession \\
\hline & Professions' trend \\
\hline & Young person's social network \\
\hline \multirow{2}{*}{ Supply of professions mismatch the demands of the labour market } & Complicated situation of labour market for youth \\
\hline & Problems of the labour market \\
\hline \multirow{6}{*}{$\begin{array}{l}\text { The role of professional qualifications and personal } \\
\text { characteristics }\end{array}$} & Professional suitability \\
\hline & Practical experience \\
\hline & Personal qualities \\
\hline & Motivations for activities \\
\hline & Young people without qualifications \\
\hline & Gender issues \\
\hline
\end{tabular}


'it might be slightly harder for young mothers to return to labour market after a longer pause, i.e. one or two years' (Interview No. 8). Job seeking after maternity leave also has certain specifics: a young mother's competencies are questioned, there are speculations about frequent sick leaves as small children get sick quite often: 'an employer thinks that if he hires you, and you have a small child, the child will be frequently ill, you will have sick leaves, and they will need to look for people to cover you' (Interview No. 7). This attitude among employers partially promotes deviations from the normative path: marriage and children are put off for a later stage, when career situation becomes more favourable for having children. Such position among employers make young people worry about financial issues: if a young family raises a child and fails to find a job, the family faces material problems.

Young people in rural or remote regions may also be attributed to the risk group of long-term unemployed youth. Young people who leave homes to study in bigger regional centres usually do not return home and choose to stay in a bigger city instead, where there are bigger chances to find a job: 'you naturally stay in a bigger city with more business, more chance to be looked for, to find a job you want' (Interview No. 7); 'among those who leave homes to study, only about 1 per cent come back $<\ldots>$ they become estranged from village' (Interview No. 5). On the other hand, the problem could be linked to lack of entrepreneurship of the youth, i.e. young people miss information about business opportunities, offered support. Less tax burden on business established by young people might be the solution to encourage young people to stay or just come back to the village and develop and implement their business ideas there.

Table 2 represents categories and subcategories reflecting youth situation, problem areas and future prospects in the process of transition from education to employment.

According to experts, Lithuanian youth is in the period of changes: paid education, high level of unemployment, more opportunities for voluntary work and entrepreneurship in young person life course. As a result of professions' trend and opinion about prestigious profession, there is lack of specialists in the area of information technologies, biochemistry or engineering. Moreover, social network, e.g. relatives and acquaintances' contacts, employment relations as young person's social capital help to find the well-paid job.

\section{Conclusions}

There is a lack of empirical research or studies in Lithuania targeted towards comprehensive analysis of youth transition pathways from education to the labour market. Carried out semi-structured interviews with the experts representing different domains (labour market, education, policy making, policy implementation) allows distinguishing the following transition from education to the labour market trends and perspectives for youth employment:

- Youth inadequate self-esteem has been identified as one of the drawbacks of young age. Experts consider young people to be inadequate in evaluating themselves, focusing on higher pay, not realizing they lack experience required by a certain profession or workplace. Probation period for a young person should be the period when he/she discovers his/her potential for employment, abilities of learning and acquiring new skills necessary for professional activity

- Experts interviews have revealed that the choice of a future profession depends on how prestigious, trendy the profession is, whether the studies are easy or not, as well as on friends and parents' influence. Most of the experts stated that a young person's choice of profession is conditioned by trends, popularity and prestige of specialities. Preference towards popular and trendy professions may be related to the character of the studies. Experts suggest that social sciences may seem an easier study path if compared to information technologies, biochemistry or engineering. Profession relevant for current labour market and experience, ability to perform specific tasks remain the most important criteria in finding the first job. According to the experts, labour market is oversaturated with representatives of social sciences; there is the lack of people coming from exact, engineering sciences; therefore, young people who have acquired currently untrendy professions have the best prospects for successful integration into labour market.

- Another important factor is social network of young person in both choosing a profession and seeking for a first stable job. Relatives and friends' influence is important not only in choosing a profession and deciding on the life path, but also in job seeking and starting a career. Relatives and acquaintances' contacts, employment relations are among the major mechanisms for finding a job.

- The interviewed experts named several risk groups such as young women and young mothers, recent secondary school male graduates and youth living in rural or remote areas. However, there are different limitations for each risk factor in job seeking or career development.

- Experts also stressed that Lithuania misses more profound labour market forecasts that could help a young person find the right path in choosing the profession of his/her life. It is also possible that the problem of non-compliance between a profession and labour market demands could be related to the above mentioned motive of choosing the profession - the trend. Youth unemployment is related not only to national and global economic difficulties, but also with the issues such as non-compliance of the acquired profession to the market demand, lack of professional training and competencies.

\section{References}

1. Allmendinger, J. (1989). Educational systems and labour market outcomes. European Sociological Review, 5, 231-250.

2. Beresnevičiūtè, V., Poviliūnas, A. (2007). Integration of Master Studies Graduates into Labour Market: Analysis of the Results of 
Sociological Survey. Sociologija. Mintis ir veiksmas, 1, (19), 88103.

3. Biffl, G. (2008). Migrant women and youth: the challenge of labour market integration. WIFO Working Papers, No. 320, May 2008.

4. Bucher A. (2008). Youth Employment and Labor Market Integration: A Learning Approach, Universite du Maine, Faculte de Droit et de Sciences Economique, p. 1-21.

5. Coenjaerts, C., Ernst, Ch., Fortuny M., \& Pilgrim, M. (2009) Promoting pro-poor growth: employment, chapter 'Youth employment'. OECD, p. 119-131.

6. Cuesta, M.B1. (2005). Youth labour market integration in Spain: Search time, job duration and skill mismatch. Spanish Economic Review, 7, p. 191-208. http://dx.doi.org/10.1007/s10108-005-00977

7. Gangl, M. (2003a). Returns to education in context: individual education and transition outcomes in European labour markets. In W. Muller, M. Gangl (Eds.). Transitions from Education to Work in Europe. Oxford: Oxford University Press. http://dx.doi.org/10.1093/0199252475.003.0006

8. Gangl, M. (2003b). The structure of labour market entry in Europe: a typological analysis. In W. Muller, M. Gangl (Eds.). Transitions from Education to Work in Europe. Oxford: Oxford University Press. http://dx.doi.org/10.1093/0199252475.003.0004

9. Garonna, P., \& Ryan, P. (1991). The regulation and deregulation of youth economic activity. In P. Ryan, P. Garonna, R. Edwards (Eds.). The Problem of Youth. London: Macmillan.

10. Gleeson, D., \& Keep, E. (2004). Voice without accountability: the changing relationship between employers, the State and education in England. Oxford Review of Education, 30, 1, 37-63. http://dx.doi.org/10.1080/0305498042000190050

11. Gracey, S., \& Kelly, S. (2010). Changing the NEET Mindset: Achieving More Effective Transitions between Education and Work London: LSN Centre for Innovation in Learning.

12. Green, F. (2009). Job quality in Britain, UKCES Praxis Paper No. 1, Wath-upon-Dearne: UK Commission for Employment and Skills.

13. Grimshaw, D., \& Rubery, J. (2007). The Undervaluing of Women's Work. Manchester: Equal Opportunities Commission.

14. Hodkinson, P., Sparkes, A., \& Hodkinson, H. (1996). Triumphs and Tears: Young People, Markets and the Transitions from School to Work. London: David Ulton.

15. Howarth, C., \& Kenway, P. (2004). Why Worry Any More about the Low Paid? London: New Policy Institute.

16. Human capital. How what you know shapes your life (2007) Organization for economic co-operation and development, OECD.

17. Ianneli, C., \& Raffe, D. (2007). Vocational Upper Secondary Education and the Transition from School. European Sociological Review, 23, 1, 49-63. http://dx.doi.org/10.1093/esr/jcl019

18. Integration of Greek University Graduates, Hellenic Observatory Papers on Greece and Southeast Europe, GreeSE, Paper No. 32, p. $1-42$.

19. Karamessini, M. (2010). Transition Strategies and Labour Market. GreeSE Paper, No 32

20. Keep, E. (2012). Youth Transitions, the Labour Market and Entry into Employment: Some Reflections and Questions. SKOPE Research Paper, No. 108

21. Keep, E., \& James, S. (2010). Recruitment and selection: the great neglected topic. SKOPE Research Paper, No. 88.

22. Livingstone, D. (2010). 'Job requirements and workers' learning: formal gaps, informal closure, systemic limits. Journal of Education and Work, 23, 3, 207-231. http://dx.doi.org/10.1080/13639081003785732

23. London Economics (2011). The returns to higher education qualifications. BIS Research Paper, No. 45.

24. Maguire, S. (2010). 'I just want a job': what do we really know about young people in jobs without training? Journal of Youth Studies, 13,3 3, 317-333. http://dx.doi.org/10.1080/13676260903447551

25. Matsumoto, M., \& Elder, S. (2010). Characterizing the school-towork transitions of young men and women: Evidence from the ILO School-to-work transition surveys Employment Sector. Employment Working Paper, No. 51.

26. Mihaela, D., Coralia, A., \& Cosmin, M. (2010). Labor market integration of higher education economic graduates. Annals of the University of Oradea : Economic Science, 1, (1), 196-201.

27. Müller, W., \& Gangl, M. (eds). (2003). Transitions from Education to Work in Europe: The Integration of Youth into EU Labour
Markets. Oxford: Oxford University Press. http://dx.doi.org/10.1093/0199252475.001.0001

28. Okunevičiūtè-Neverauskienè, L., \& Moskvina, J. (2008). The problems of socially vulnerable youth integration into labour market. Filosofija. Sociologija, 19, 2, 41-54.

29. Okunevičiūtè-Neverauskienè, L., \& Šlekienè, K. (2008). NGO's influence on youth integration into labour market. Filosofija. Sociologija, 19, 4, 10-21.

30. Ortega, N. (2011). The Role of Higher Education Associations in Shaping Policy That Connects Immigrations to Educational Opportunity: A Social Capital Framework. Journal of Hispanic Higher Education, 10, 41-65.

http://dx.doi.org/10.1177/1538192710391803

31. Pocius, A. (2012). Mobility of physicians and main trends of their integration in the labour market in the conditions of economic boom/crisis. Filosofija. Sociologija, 23, 2, 164-171.

32. Putnam, R.D. (1995). Bowling Alone: America's Declining Social Capital. Journal of Democracy, 6, 1, 65-78. http://dx.doi.org/10.1353/jod.1995.0002

33. Raffe, D. (2008). The concept of transition systems. Journal of Education and Work, 21, 4, 277-296. http://dx.doi.org/10.1080/13639080802360952

34. Rauner, F. (1999). School-to-work Transition: The Example of Germany. Institut Technik \& Bildung.

35. Robeyns, I. (2006). Three models of education: Rights, capabilities and human capital. Theory and Research of Education, 4, (1), 6984. http://dx.doi.org/10.1177/1477878506060683

36. Saar, E., Unt, M., \& Kogan, I. (2008). Transition from Educational System to Labour Market in the European Uninio: A Comparison between New and Old Members. International Journal of Comparative Sociology, 49, 31-59. http://dx.doi.org/10.1177/0020715207088586

37. Schoon, I. (2010). Planning for the future: Changing educational expectations in three British cohorts. Historical Social Research, 35, 2, 99-119.

38. Shavit, Y., \& Müller,W. (eds). (1998). From School to Work. A Comparative Study of Educational Qualifications and Occupational Destinations. Oxford: Oxford University Press.

39. Strathdee, R. (2001). Changes in Social Capital and School-to-Work Transitions. Work, Employement \& Society, 15, 311-325. http://dx.doi.org/10.1177/09500170122118977

40. The Well-being of Nation. The role of human and social capital. Education and skills (2001). Organization for economic cooperation and development, OECD.

41. Toynbee, P. (2003). Hard Work: Life in Low-Pay Britain, London: Bloomsbury. UKCES (UK Commission for Employment and Skills) (2009). Ambition 2020: World Class Skills and Jobs for the UK, Wath-upon-Dearne: UKCES.

42. UKCES (2010). Skills for Jobs, Today and Tomorrow. The National Strategic Skills Audit for England, 1: Key Findings, Wath-uponDearne: UKCES.

43. UKCES (2011). The Youth Inquiry: Employers' Perspectives on Tackling Youth Unemployment. Wath-upon-Dearne: UKCES.

44. Van der Velden, R., Welters, R., \& Wolbers, M. (2001). The Integration of Young People into the Labour Market within the European Union: the Role of Institutional Settings, Research Centre for Education and the Labour Market, Faculty of Economics and Business Administration, Maastricht University, 1-63.

45. Van der Velden, R., \& Wolbers, M. (2003). The Integration of Young People into the Labour Market: The Role of training systems and Labour Market Regulation. In W. Mülller, M. Gangl (eds.). Transitions from Education to Work in Europe. The Integration of Youth into EU Labour Markets, 186-211. Oxford: Oxford University Press.

46. Zittoun, T. (2007). Symbolic resources and responsibility in transitions. $\quad$ Young, 15, 193-211. http://dx.doi.org/10.1177/110330880701500205

47. Austrian Institute for Economic Research (WIFO), 29 April 2008 Thematic Review seminar of the European Employment Strategy, 118. 


\section{R. Brazienè, A. Dorelaitienè}

Jaunimo perèjimas iš švietimo sistemos ị darbo rinką: Lietuvos atvejis

\section{Santrauka}

Šiame straipsnyje analizuojama jaunimo perejjimo iš švietimo sistemos i darbo rinką situacija, perejjimo iššūkiai ir problemos. Pasitelkiant teorinius požiūrius ir empirinius radinius, siekiama atskleisti sékmingos integracijos iš švietimo sistemos i darbo rinką aspektus, pagrindines galimybes ir esminius iššūkius.

Jaunimo ịsitraukimas ị darbo rinką ir sékmingas užimtumas yra viena iš svarbiausių problemų ne tik Lietuvoje, bet ir daugelyje Europos šalių. Prieš tris dešimtmečius jaunuolio perèjimas iš švietimo sistemos ị darbo rinką Centrinès ir Rytų Europos šalyse buvo gana aiškus: priklausomai nuo mokymosi rezultatu, kiekvienas jaunas žmogus gaudavo valstybès garantuotą pirmaji darbą. Tačiau per pastaruosius 20 metų dèl ekonominių, socialinių ir kultūrinių pokyčių jaunimo situacija pasikeitè: jauni žmonès derina studijas ir darbą ar studijų baigimą atideda vèlesniam laikui. Tuo tarpu jaunimo situacija darbo rinkoje yra gana problemiška: jaunimo nedarbo rodikliai dideja, o jaunuoliui susirasti ilgalaiki ir stabilų darbą darosi vis sunkiau, nes darbo rinka iš potencialaus darbuotojo reikalauja darbo patirties, atitinkamos srities žiniu ir igūdžių, ko dažnas jaunuolis, tik pabaigęs studijas aukštojoje mokykloje neturi.

Jaunimo perèjimo iš švietimo sistemos i darbo rinka ir jaunimo užimtumo klausimas pastaruosius 30 metų yra Vakarų šalių mokslininkų dèmesio centre. Jaunimo perèjimą i švietimo sistemą ir ị darbo rinką nagrinejja Gracey, Kelly (2010); Hodkinson, Sparkes, Hodkinson (1996); Keep, James (2010b); Keep, James (2010); Raffe (2008); Muller, Gangl (2003); Shavit, Müller (1998), Gleeson, Keep (2004); Livingstone (2010) domisi švietimo sistemos kuriamų produktų neatitikimu darbo rinkos lūkesčiams, Green (2009), Howarth, Kenway (2004) domisi situacija darbo rinkoje (laikinais darbais, darbo lankstumu ir pan.). Užsienio šaliu moksliniai tyrimai jau prisideda prie jaunimo sékmingesnès integracijos i darbo rinka ir siekia spręsti jaunimo nedarbo problemą, tuo tarpu Lietuvoje šia problema susirūpinta pastaraisiais metais.

Straipsnyje siekiama atsakyti ị šiuos probleminius klausimus: kokie yra jaunimo perejimo iš švietimo sistemos i darbo rinką pagrindiniai iššǔkiai? Kokios įsidarbinimo perspektyvos jaunimui Lietuvoje? Kokia darbo rinkos politika yra vykdoma siekiant pagerinti jaunimo situaciją darbo rinkoje? Kaip vykdomos socialinès politikos priemonès gali pagerinti jauno žmogaus gyvenimo kokybę?

Šio straipsnio tikslas yra atskleisti pagrindines galimybes ir esminius iššǔkius jaunimui pereinant iš švietimo sistemos ị darbo rinką. Jaunimo perejimas iš švietimo sistemos i darbo rinką yra apibrèžiamas kaip dinaminis procesas, jauno žmogaus (15-29 metų) gyvenimo etapas, kai igijęs kvalifikaciją jaunuolis tampa pilnaverčiu darbo rinkos dalyviu dirbdamas nuolatinị darbą, kuris teikia pasitenkinimą. Atkreipdami dẻmesi i jaunimo gyvenimo būdo neatitikimą anksčiau nusistovejjusiai normatyvinei biografijai, mokslininkai atkreipia dèmesị i tris perèjimo etapus: ịvykęs perèjimas (kai jaunuolis turi nuolatinị darbą, kuriuo yra patenkintas), perejimo procesas (kai jaunuolis neturi darbo ar dirba, tačiau neturi darbo sutarties) ir perèjimas dar neprasidèjęs (kai jaunuolis yra ugdymo/si procese). Vokietijoje perẻjimas iš švietimo sistemos ị darbo rinką apima keturis aspektus: individualų, institucinị (švietimo sistemos institucijos), mokymo rinkos (perẻjimą iš mokyklos i profesini parengimą), darbo rinkos (perejimą iš profesinio mokymosi $\mathfrak{i}$ darbo rinką). Darbo rinka ir švietimo sistema perèjimo procese yra svarbiausi institutai: švietimo sistema rengia kvalifikuotus specialistus darbo rinkai, o sékminga jaunimo integracija i darbo rinką gali priklausyti nuo pozityvaus ir konstruktyvaus dialogo tarp švietimo sistemos ir darbo rinkos.

Ivvairiapusiai ir išsamiai suvokti perèjimo procesą gali padèti nacionalinio lygmens švietimo sistemos, darbo rinkos, politikos igyvendinimo specialistai, nuolat susiduriantys su jaunimo peréjimo iš švietimo sistemos i darbo rinką klausimais. Todèl siekiant atskleisti jaunimo perejjimo iš švietimo sistemos ị darbo rinką aspektus, Lietuvos mokslo tarybos finansuojamame projekte,, Jaunimo perejjimas iš švietimo sistemos i darbo rinką: stebèsenos sistemos parengimas" (TRANSMONITOR) buvo atlikti nacionalinio lygmens darbo rinkos, švietimo, ekonomikos sričiu ekspertu pusiau struktūruoti interviu.

Kaip atskleidè interviu analizè, jaunimo situacija darbo rinkoje yra išties problemiška. Ekspertų nuomone, jaunimo situacija darbo rinkoje yra sudètinga ne tik dèl ekonominiu sunkumu šalyje ir pasaulyje, bet ir dèl pasirinktų profesijų neatitikimo darbo rinkos poreikiams, jaunų žmoniu, baigusiu studijas, kompetenciju ir patirties trūkumo. Darbo rinkos tendencijos atskleidžia, jog tam tikrų sričiu specialistų trūksta, o tam tikrų sričiu - perteklius. Perteklius dažniausiai yra susijęs su socialinių mokslų studijomis, kurias renkasi jaunuoliai kaip lengviau studijuojamas. Biomedicininiai, technologiniai, inžineriniai mokslai yra rečiau pasirenkama studiju kryptis dèl šiu mokslu sudètingumo, mažesniu galimybių suderinti studijas ir darbą. Tačiau būtent šių mokslų diplomas jaunuoliui šiuolaikineje visuomenèje gali garantuoti nuolatinę darbo vietą. Kitas svarbus veiksnys, kuri atskleidè ekspertu interviu, yra socialinio tinklo svarba jauno žmogaus kelyje tiek renkantis profesiją, tiek ieškant pirmojo nuolatinio darbo baigus studijas. Socialinis tinklas gali būti suprantamas kaip tam tikra socialinio kapitalo forma, apimanti jaunuolio tèvus ir draugus, o turimi socialiniai tinklai jaunuoliui gali būti naudingi patikimais patarimais apie perspektyvias profesijas ir darbo rinkos nišas.

Socialinis tinklas, perspektyvi profesija nèra vieninteliai sékmingos integracijos i darbo rinką mechanizmai. Ekspertai pastebi, jog pirmojo darbo ieškojimuose yra svarbios ir jaunuolio asmeninès savybès: komunikabilumas, iniciatyvumas, noras mokytis ir išmokti. Sparčiai besivystant technologijoms, svarbus jauno žmogaus gebėjimas prisitaikyti prie kintančių darbo sąlygų, gebejimas greitai išmokti naujų dalykų ir susirasti atsakymus i rūpimus klausimus. Todèl vertinamas jauno žmogaus aktyvus ịsitraukimas i neformalią veiklą studijų metų - tai, pasak ekspertų, atskleidžia jauno žmogaus potencialą mokytis, tobulèti, gebejimą suderinti keletą veiklų.

Analizė atskleidè ir jaunimo, esančio rizikos grupejje patirti ilgalaiki nedarba, situaciją. Darbo rinkos, švietimo sistemos, politikos igyvendinimo specialistų nuomone, jaunuoliai, baigę tik vidurinę mokyklą ir neigiję kvalifikacijos bei jaunuoliai, gyvenantys atokiouse regionuose ar kaimo vietovèse, turi mažiau šansu susirasti nuolatinius darbus, kuriais būtu patenkinti. Jaunos merginos ir jaunos mamos taip pat buvo išskiriamos kaip jaunuoliu grupe, kuriai lytis ir amžius apriboja sékmingos integracijos ị darbo rinką procesą. Tai susiję su stereotipinèmis darbdavių nuostatomis, jog jaunos moterys greitu laiku taps mamomis, o jaunos mamos yra praradusios reikiamus igūdžius ir žinias. Ekspertu ¡žvalgos leidžia teigti, jog jaunimo situacija perẻjimo iš švietimo sistemos i darbo rinką procese yra sudetinga ir reikalaujanti ìvairių sričių specialistų dèmesio.

Reikšminiai žodžiai: jaunimas, švietimo sistema, darbo rinka, perejjimas iš švietimo sistemos ị darbo rinką.

First received: July, 2012

Accepted for publication: September, 2012 